\title{
THE USE OF SKIN GRAFTING TO DISTINGUISH BETWEEN MONOZYGOTIC AND DIZYGOTIC TWINS IN CATTLE
}

\author{
D. ANDERSON, R. E. BILLINGHAM*, G. H. LAMPKIN and \\ P. B. MEDAWAR
}

From the Department of Zoology, University of Birmingham, and the Animal Breeding and Genetics Research Organisation, Edinburgh

\section{CONTENTS}

Received 2.iv.51

1. Introduction . . . . . . . . . . . 379

2. A Note on the Skin Homograft Reaction . . . . . 381

3. Methods . . . . . . . . 382

(i) Preparation of the donor area . . . . . . . 383

(ii) The recipient area $. \quad . \quad . \quad . \quad . \quad . \quad . \quad 383$

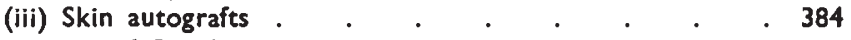

4. Experimental Results-

(i) The exchange of skin homografts between unrelated cattle 385

(ii) The exchange of homografts between allegedly monozygotic twins . . . . . . . . . 387

(iii) The exchange of homografts between allegedly dizygotic

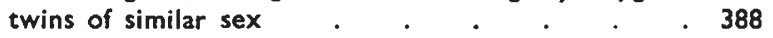

(iv) Exchange transplantations between full siblings of separate birth . . . . . . . . . . 391

(v) Exchange transplantations between dizygotic twins of unlike sex . . . . . . . . . 392

5. Discussion-

(i) The use of skin grafting for twin diagnosis. • . 394

(ii) The cause of the anomalous behaviour of grafts exchanged between dizygotic twins. . . . . . 394

6. Summary . . . . . . . . . . . 396

7. References . . . . . . . . . . . 397

\section{INTRODUCTION}

CATTLE twins have the same importance to geneticists as human twins, inasmuch as they make it possible to distinguish between inborn and acquired character differences by experiments of classical simplicity of design. Unfortunately, there is no completely reliable and objective method of distinguishing between monozygotic and dizygotic twins in cattle, and Dr H. P. Donald, who has discussed the problem in a recent issue of this journal (vol. 5, no. I), therefore encouraged us to find out if the interchange of skin grafts between twins could serve such a purpose. The principle is obvious enough. It is an empirical fact that skin grafts do not long survive transplantation between mammals of ordinary genetic diversity (whether between unrelated individuals, siblings, or parents and offspring). "Homografts," as such grafts are called, should therefore fail when interchanged between

* British Empire Cancer Campaign Research Fellow. 
dizygotic twins, which (according to a theory which will be shown to need some qualification when applied to cattle) are no more closely related genetically than ordinary siblings. On the other hand, it must be regarded as a genetical truism that grafts exchanged between monozygotic twins behave like autografts, i.e. grafts transplanted from one part to another of the same individual. Human clinical practice provides plenty of evidence that this is indeed the case, and skin grafting has already been used to clear up confusions of parentage (Franceschetti, Bamatter and Klein, 1948; McIndoe and Franceschetti, 1950). The fact that skin grafts may be interchanged with success among mice of highly inbred strains is, of course, a consequence of their becoming genetically more alike, but it has no practical bearing in the problem to be discussed here.

There is therefore a clear prima facie case for supposing that the interchange of skin grafts should make it possible to distinguish with complete certainty between monozygotic and dizygotic twins in cattle. We at first suspected that the problem of graft "dosage" might be a serious technical obstacle. The reaction against skin homografts becomes faster and more vigorous as the quantity of skin that is grafted increases, and the relative "dosage" of skin that can be grafted to cattle is obviously very much smaller than with a rabbit or mouse. These misgivings proved to be ill founded. Other things being equal, the intensity of the homograft reaction varies from one species to another, and in the cow it is of such violence as to make graft dosage a matter of altogether minor importance. In spite of this dispensation, and in spite of having overcome the purely technical difficulties of grafting, it proves that skin interchange cannot be used for distinguishing monozygotic from dizygotic twins in cattle. Dizygotic twins in cattle, whether of like or unlike sex, are in some manner mutually desensitised to grafts of each other's skin-a situation which clearly corresponds to the anomalous conformity of red cell agglutination types described in dizygotic cattle twins by Owen (1945) and Owen, Davis and Morgan (1946).

In section 4 of this paper, we shall describe the behaviour and fate of grafts exchanged (i) between unrelated cattle; (ii) between twins classified by experienced observers as monozygotic; (iii) between twins likewise classified as dizygotic; (iv) between full siblings of separate birth; and ( $v$ ) between twins of different sex, and thus beyond question of dizygotic origin. We improved our operative methods while the work was in progress, and the majority of tests made use of a technique which we regard as very satisfactory-the transplantation of a number of individual discs of skin (" pinch" grafts) from the dorsum of the ear to the skin of the dorso-lateral aspect of the thorax-the "withers." The grafts were thus permanently "labelled" (see below) by having (and of course retaining, if they survived) the distinctive properties of ear skin. Wherever the colour patterns of donors and hosts allowed it, they were labelled by intrinsic 
colour differences as well- - e.g. by grafting pigmented skin to nonpigmented, or differently pigmented, recipient areas. On a number of occasions animals were repeatedly grafted from the same donor; and most animals received autografts as well as homografts to provide some estimate of the efficacy of healing uncomplicated by immunological reactions.

\section{A NOTE ON THE SKIN HOMOGRAFT REACTION*}

Skin homografts are destroyed by a mechanism that is known to belong to the general category of actively acquired immune reactions. Their initial healing is as strong as with autografts; they are as quickly and as richly vascularised, and they show the same outburst of epithelial proliferation that follows the establishment of a blood supply; and, in general, they behave just like autografts until the reaction they elicit from their host begins to overtake them. Just how soon this happens depends upon a variety of factors, of which the only two that are relevant here are $(a)$ the quantity of foreign skin that is grafted: the higher the dosage, the shorter the survival time; and $(b)$ the antigenic and therefore the genetic relationship between donor and recipient : the smaller the difference, the longer the time of survival. The second factor quantitatively outweighs the first.

When an animal has already received and reacted against homografts from the same donor, the sequence of events is modified. The second set of homografts is reacted against much more quickly; the vascular system of the grafts is soon disrupted, leaving them in an ischæmic condition; and epithelial proliferation is suppressed. This " immune" effect provides a valuable confirmatory test of incompatibility which we have repeatedly made use of.

The survival time of homografts exchanged between ordinary siblings or unrelated cattle has in our experience proved to be in the neighbourhood of ten days. (More exact information will be given below.) The reaction that brings about such rapid breakdown is " acute," and it is associated with an inflammatory reaction of extreme violence. "Acute" breakdown may be watched and diagnosed with certainty by naked eye inspection. The graft swells, because it is inflated with œdematous fluid and with frank hæmorrhages, and changes colour from the delicate pink associated with ordinary vascularisation to various shades of dirty yellow, brown or black. Meanwhile it hardens, so that instead of being resilient it moves as a whole when palpated ; its rim becomes free from the surrounding host tissue, to which it had earlier united; the surface epithelium weakens and becomes wet and pasty, instead of firm, shiny and dry, and may be stripped off to reveal the discoloured and pitted surface of the dermis below. In due course the graft simply becomes a dry

* See Medawar (1944, 1945, 1946a). 
and necrotic scab, which is undermined by the ingrowth of the host's own epithelium so that it eventually drops away.* Histological examination of homografts in the period that precedes final breakdown reveals all the phenomena of acute inflammation. Lymphocytes are the dominant inflammatory cell; the presence of granulocytes in any abundance is a consequence of secondary infection.

We shall have occasion in the text to describe a much milder, chronic breakdown reaction, the progress and completion of which cannot always be followed without error by mere naked eye inspection. Weak chronic reactions have been found to occur in grafts interchanged between certain dizygotic twins.

It is proper to say that other variables which govern the survival time of homografts and the quality of the reaction elicited by them have been eliminated in our experiments. The species factor is constant; the grafts are all orthotopic (i.e. are grafts of skin into positions formerly occupied by skin), so that peculiarities of blood supply or lymphatic drainage are irrelevant; and any physiological stress caused by operation, such as might prolong the survival time of homografts by causing the liberation of cortisone-like adrenal steroids (Billingham, Krohn and Medawar, I95I), is manifestly of trivial importance.

\section{METHODS}

Over most of the body surface bovine skin (plate I, fig. I) consists of three major layers: (a) a fully stratified superficial epidermis (plate I, fig. 2) and its derivatives, the hairs, the bases of which penetrate deeply into $(b)$ a very thick, tough dermis which is firmly united to $(c)$ a layer of striped muscle, the "panniculus carnosus." Between this layer of muscle and the overlying dermis run the principal blood vessels and lymphatics of the skin. The epidermis of skin bearing pigmented hairs is itself usually pigmented.

The skin of the dorsum of the ear (plate I, fig. 3) differs from that of the general body surface in that it bears a sparser hair crop, its dermis is thinner and composed of finer collagen fibres, and it is rather loosely united to the fascial layer that overlies the ear cartilage, a panniculus carnosus being absent.

After a few preliminary trials in which grafts were cut from the exceedingly thick tough skin of the dorso-lumbar region, this source was abandoned for the thinner and more mobile skin of the dorsum of the ears, from which it was possible to cut thinner grafts. A general description of the technique of experimental skin grafting is given by Billingham and Medawar (I95I).

* The growth of native epithelium over the collagenous remnant of a broken-down homograft forms a scar that may be quite easily mistaken for a surviving ear skin homograft, if regular inspections have not been carried out. Three criteria distinguish such a scar from a genuine ear skin graft : it is always bald; its surface is smooth and shiny, instead of finely reticulate and matt; and it is rounded and raised up, whereas ear skin grafts are flat and, because of their thinness, recessed below the plane of the skin surface. 


\section{(i) Preparation of the donor area}

After a preliminary close-clipping, shaving and thorough scrubbing with soap and water the dorsum of the ear was rinsed with a $0 \cdot I$ per cent. solution of "Cetavlon" in 70 per cent. spirit which was allowed to dry on. Local anæsthesia was then induced by the subcutaneous injection of a total of 5-IO c.c. of a 2 per cent. solution of ethocaine hydrochloride (such as "Novutox") at several sites below the surface of the prepared skin.

A number of separate "pinch" grafts were cut from the donor area so prepared--each a disc of skin, IO- $12 \mathrm{~mm}$. in diameter and comprising the epidermis and the full thickness of the dermis. To cut each graft a small tent of skin was raised with the aid of fine, sharp forceps which had been so adjusted that their points could be brought together with a pincer-like action, and the base of the tent was then cut through by horizontal incisions with a No. I 2 scalpel. Even in young animals as many as 24 such grafts could easily be cut from the dorsum of one ear. Immediately after cutting the grafts were placed raw side down in a sterile Petri dish on the bottom of which had been placed a piece of filter paper soaked in Ringer's solution or normal saline. The donor area required no special treatment apart from a thick dusting with a sulphonamide powder. A protective scab rapidly formed over each graft donor site and this normally came off after about ten days, when the raw area had been fully resurfaced by epithelial ingrowth from the margins of the lesions.

\section{(ii) The recipient area}

For success a skin graft must be transplanted to a vascular bed and held in place under moderate perpendicular pressure until primary healing is complete. In our earlier experiments, grafts were transplanted to the outer aspect of the forelimb above the "knee" (plate I, figs. 4, 5, 6) and held in place by bandages and a plaster casing. Besides being extremely awkward for the surgeon, this site proved to be unreliable, for the plaster sheath sometimes slipped and several of the grafts were consequently lost. It was therefore abandoned for one located fairly high dorso-laterally on the thorax, just posterior to the scapula (i.e. on the side of the " withers") (plate I, figs. 7, 8, 9). The hair over a fairly extensive rectangular area was close-clipped and the central region, where the actual graft beds were to be prepared, was shaved and anæsthesia induced by infiltration with Io-I 5 c.c. of local anæsthetic. A separate bed to receive each graft was then cut, exactly as one cuts a " pinch" graft, except that the graft itself is discarded, only its bed being required. Graft beds prepared in this way increase in depth from the margin to the centre, where they extend down to the vascular fascial planes overlying the panniculus carnosus. Some care was taken to make the beds of such a shape and size that the grafts fitted into them exactly. 
After removing all free blood from the graft beds with sterile gauze swabs, the grafts were pressed firmly into position. After the transplantation of the grafts a sheet of home-made tulle gras (a self-adherent dressing prepared by impregnating fine open-wove bandage with vaseline) was pressed smoothly over the operation field so as to cover the grafts completely and leave a marginal overlap of $\mathrm{I}-2 \mathrm{cms}$. Immediately over the tulle was placed a pressure pad of approximately the same size and comprising several thicknesses of sterile gauze. To prevent these dressings from being displaced the area of clipped skin round the operation field was painted with a latex solution to make it sticky, and several lengths of 4 -inch wide bandage were then pressed firmly into such a position that they intersected at right angles across the immediate graft dressings, thereby preventing side-slip. Finally, to secure adequate vertical pressure, a large square pad of cotton wool, about I $2 \times I_{2}$ inches, was placed over the entire field and held in this position under moderate compression by means of a hessian truss which was passed right round entire thorax, the free ends being laced together ventrally (plate I, fig. 8). This technique has given complete success in animals ranging in age from a few weeks to a year or more. As many as 28 grafts have been transplanted to this site and there is no reason to suppose that it would not accommodate many more if required.

Primary inspection was carried out seven to fourteen days after operation. Owing to the powerfully adhesive properties of the latex no attempt was made to remove all the dressings at this stage. An inspection window was cut over the actual graft field and after inspection the young grafts were protected from the animal's attempts to lick them by covering them with a sheet of gauze which was secured to the old dressings with latex solution. This secondary dressing was normally removed after five to seven days, no other being necessary.

\section{(iii) Skin outografts}

As mentioned above, pigmented ear skin-nearly always red or black in the animals available-was whenever possible transplanted to recipient areas cut in white skin. The fate of skin autografts was studied in some detail to provide a standard against which to compare the fate of homografts. In almost all our experiments a group of autografts was transplanted simultaneously to the same operation field to act as "controls." As was to be expected, these autografts invariably "took" provided that the dressings remained in place during the critical period of primary healing, which lasts three or four days. By the first inspection, normally carried out eight to twelve days post-operatively, the grafts had healed in completely and their margins, though visibly distinct, were firmly united to the adjacent host skin. From the surface of the grafts a dry, scaly cuticlethe "ghost graft"-could be cleanly peeled off to reveal a dry, 
healthy-looking epithelium which was normally slightly pinkish in colour. In grafts cut from deeply pigmented skin it was observed that the pigmentation of the grafts underwent a considerable though transient dilution, which reached its peak by about the 3 oth day when the centres of the grafts were often completely depigmented. Recovery of pigmentation was often not complete until about the 5oth day. The more peripheral regions of the grafts rarely manifested this severe bleach-out, and from about the 2 oth day the normal depth of colour returned progressively from this marginal region inwards.

With pigmented grafts transplanted to white skin it was observed that the pigmentation of the graft encroached progressively upon the surrounding white host skin from about the zoth day onwards, so that after I oo days a graft had become surrounded by an annulus of pigment spread I $\mathrm{cm}$. or more in width (plate I, figs. 4, 5, 6). This spread of pigmentation did not affect the hairs in the white skin into which it encroached (plate I, fig. 5), and the hairs remained white. The process is exactly analagous to that which is known to occur in the guinea-pig (Billingham and Medawar, I948, I950).

The hair follicles carried over with the grafts undergo a phase of cystic hyperplasia during which the remains of the old hair shafts are shed. All the hairs that later grow from the grafts are from follicles of new formation. New hairs do not begin to pierce the graft surface until about the 4oth day.

As a rule the grafts remained permanently recessed, lying slightly below the general level of the host skin. This is undoubtedly due to the fact that the dermis of ear skin is very much thinner than that of body skin.

\section{EXPERIMENTAL RESULTS}

\section{(i) The exchange of skin homografts between unrelated cattle}

As a preliminary to attempting to differentiate between mono- and dizygotic twins, it was of course necessary to confirm that skin homografts exchanged between unrelated cattle of the same or, of course, different breeds elicit and succumb to a homograft reaction of appreciable intensity.

Skin homografts were reciprocally exchanged $(a)$ between six pairs of unrelated animals which were individually of twin birth; and (b) between four pedigree Ayrshire cattle, each of separate birth (i.e. not members of twin pairs), in such a manner that each animal received homografts from each of the other three (see fig. I). In all animals the results were perfectly clear-cut and consistent. Although there was ample evidence that these grafts had at first healed soundly, they rapidly became swollen, cedematous and severely inflamed. The graft surface became weak and pasty so that it could easily be picked off with fine forceps to reveal a grossly hæmorrhagic dermis. The rims or margins of the grafts became free and as the graft became 
dry, discoloured and necrotic, it was progressively undermined by ingrowth of native epithelium from the margins. Finally the ingrowing sheet of native epithelium cut through the slender central stalk of attachment of the scab-like graft residue, which then dropped off. Histologically this " acute" homograft reaction was accompanied by round cell infiltration of the dermis and even the epidermis of the graft. In no animal did the epithelium of a homograft survive beyond the $15^{\text {th }}$ day and in the majority breakdown was complete by the gth day.
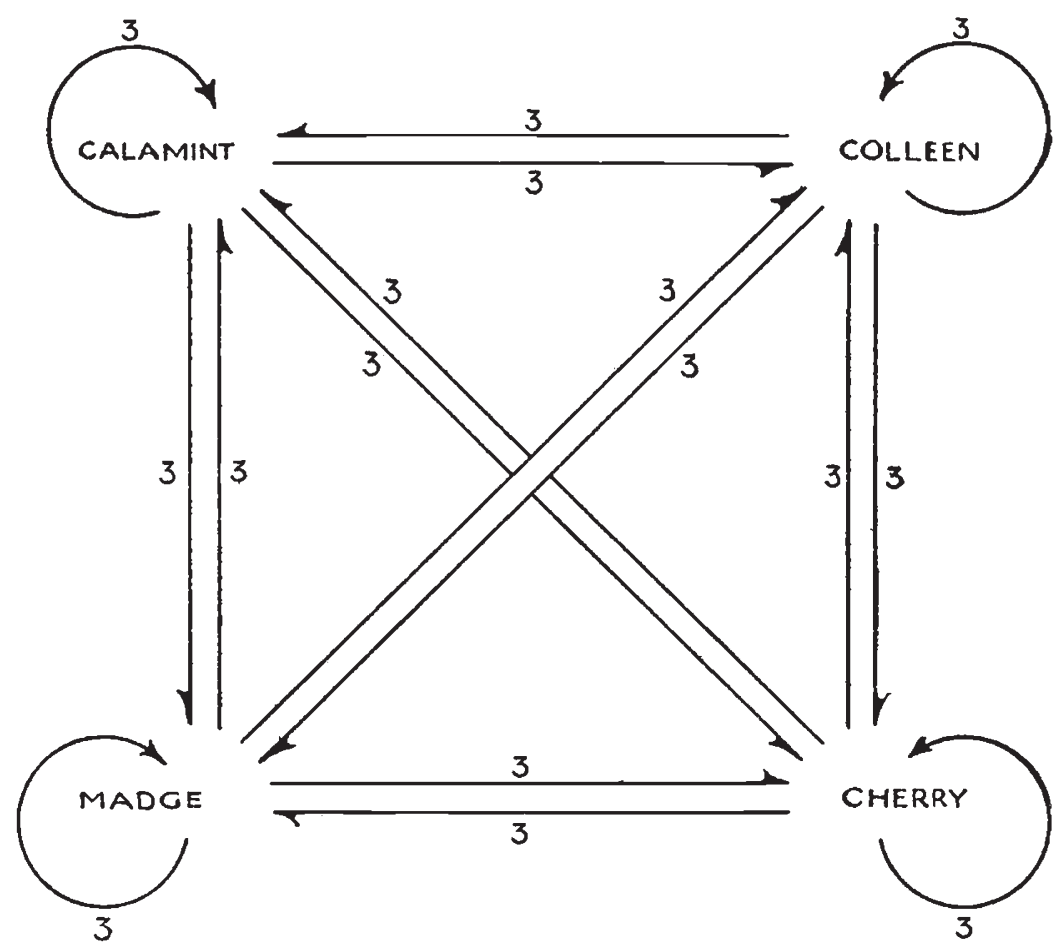

FiG. 1.-Illustrating the skin transplantation experiment carried out between four pedigree Ayrshire cattle, each of separate birth. Each animal received three homografts from each of the others and three autografts as well.

Although it was not possible to time accurately the completion of breakdown in all homografts, sufficient data were obtained to indicate that it did indeed vary within the stated limits. Moreover, no detailed information was gained concerning the effect of graft dosage. It is, however, interesting to note that, with several animals to which only a single homograft was transplanted, breakdown was nevertheless complete by the 9 th day. It is scarcely necessary to state that in the few animals to which a second homograft was transplanted from the original donor after the breakdown of a first, the second graft broke down as quickly as the first, though no attempt was made to find out if it broke down more quickly. 
These experiments made it clear that skin homografting gives rapid and conspicuous evidence of the genetic disparity between unrelated cattle of the same breed.

TABLE I

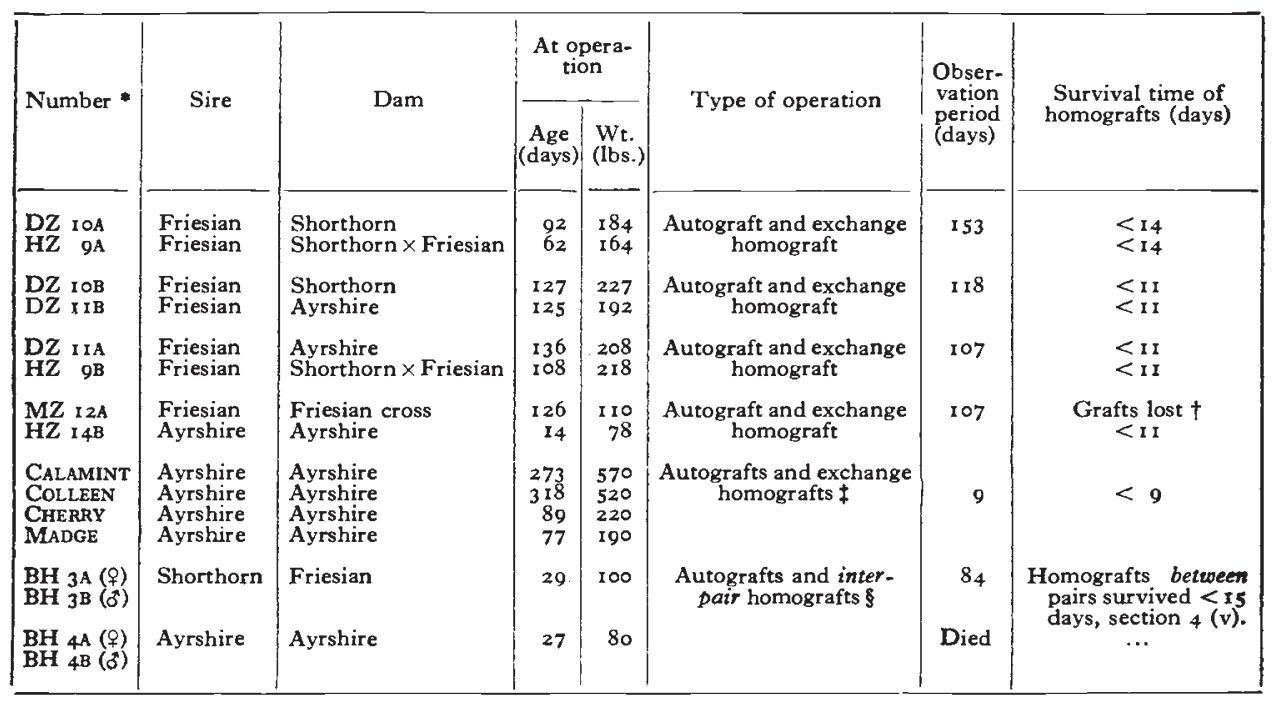

- All animals except $\mathrm{BH}_{3} \mathrm{~B}$ and $\mathrm{BH}_{4} \mathrm{~B}$ were females.

+ As a result of plaster slip in the foreleg position.

$\ddagger$ See fig. I and description in text, section 4 (i).

$\S$ See fig. 3 and description in text, section 4 (v).

\section{(ii) The exchange of homografts between allegedly monozygotic twins}

The provisional diagnosis of the monozygotic or dizygotic origin of the twins used in the experiments to be described in this section and the next was, of necessity, based on orthodox phenotypic appraisal.

Skin grafts were reciprocally exchanged in various dosagesusually not less than 6 standard pinch homografts per animalbetween the two members of each of ro separate and unrelated pairs of allegedly monozygotic twins, all except one pair being females. In every pair except one, the grafts behaved just like " control " autografts throughout the period of observation.

The one exceptional pair, MZ IA and MZ IB, operated on when 37 days old, became sufficiently unlike as they grew up to make us question their original classification as monozygotic. By this time single (pigmented) homografts exchanged between them had remained perfectly normal to outward appearance for 560 days, and each was surrounded by a wide band of black pigment spread. A confirmatory operation was nevertheless undertaken, and 24 ear skin grafts were cut from each member of the pair and transplanted, with 4 autograft controls, to the other.

When the second stage grafts were of 23 days' standing, the homografts (which should in theory have been indistinguishable from the autografts) were seen in both animals to be slightly inflamed. At the same time, 
the first-stage homografts on both animals-now $5^{84}$ days old-became much paler in colour, and the surrounding ring of pigment spread became light brown or almost straw coloured. The inflammation and the pigment dilution both subsided within the next 27 days, and the grafts became to outward appearance perfectly normal.

TABLE 2

\begin{tabular}{|c|c|c|c|c|c|c|c|c|}
\hline \multirow{2}{*}{ Number * } & \multirow{2}{*}{ Sire } & \multirow{2}{*}{ Dam } & \multicolumn{2}{|c|}{$\begin{array}{l}\text { At opera- } \\
\text { tion }\end{array}$} & \multicolumn{2}{|c|}{ Type of operation } & \multirow{2}{*}{$\begin{array}{l}\text { Obser- } \\
\text { vation } \\
\text { period } \\
\text { (days) }\end{array}$} & \multirow{2}{*}{ Notes $\dagger$} \\
\hline & & & $\begin{array}{l}\text { Age } \\
\text { (days) }\end{array}$ & $\begin{array}{l}\text { Wt. } \\
\text { (lbs) }\end{array}$ & $\begin{array}{l}\text { Homografts } \\
\text { interchanged }\end{array}$ & $\begin{array}{l}\text { Auto- } \\
\text { grafts }\end{array}$ & & \\
\hline $\begin{array}{ll}\mathrm{MZ} & \text { IA } \\
\mathrm{MZ} & \text { IB }\end{array}$ & Friesian & Friesian & 37 & $\begin{array}{l}138 \\
143\end{array}$ & I & $\ldots$ & 630 & ... \\
\hline $\begin{array}{ll}M Z & \text { IA } \\
M Z & \text { IB }\end{array}$ & Friesian & Friesian & 597 & $\begin{array}{l}884 \\
982\end{array}$ & 24 & 4 & 69 & $\begin{array}{l}\text { Second stage operation : } \\
\text { see text, section } 4 \text { (ii) }\end{array}$ \\
\hline $\mathbf{M}_{3{ }^{B}}$ & Friesian & Friesian cross & 148 & $\begin{array}{l}246 \\
195\end{array}$ & 4 & $\ldots$ & 100 & $\begin{array}{l}\text { Two calves from a set of } \\
\text { bull quadruplets }\end{array}$ \\
\hline $\begin{array}{ll}\mathrm{M} Z & 8 \mathrm{~A} \\
\mathrm{M}^{\prime} Z & 8 \mathrm{~B}\end{array}$ & Shorthorn & Shorthorn & 169 & $\begin{array}{l}202 \\
207\end{array}$ & 4 & $\ldots$ & 140 & $\ldots$ \\
\hline $\begin{array}{ll}M Z & 9 A \\
M Z & 9 B\end{array}$ & Shorthorn & Guernsey & 544 & $\begin{array}{l}802 \\
756\end{array}$ & 6 & 6 & 43 & $\begin{array}{l}\text { Animals also received inter- } \\
\text { sib grafts: see section } 4 \text { (iv) }\end{array}$ \\
\hline $\begin{array}{l}\text { MZ IOA } \\
\text { MZ IOB }\end{array}$ & Shorthorn & Shorthorn & 182 & $\begin{array}{l}248 \\
250\end{array}$ & 6 & $\ldots$ & 82 & $\ldots$ \\
\hline $\begin{array}{l}M Z \\
M Z \\
\text { I } 2 \mathrm{~A}\end{array}$ & Friesian & Friesian cross & 133 & $\begin{array}{l}210 \\
213\end{array}$ & 4 & $\ldots$ & 90 & See also section 4 (i) \\
\hline $\mathrm{MZ}_{\mathrm{I3A}}$ & Shorthorn & Shorthorn $\times$ Friesian & 489 & $\begin{array}{l}713 \\
689\end{array}$ & 6 & 6 & 18 & $\begin{array}{l}\text { Animals also received inter } \\
\text { sib grafts: see section } 4 \text { (iv) }\end{array}$ \\
\hline $\begin{array}{l}M Z \text { I } 4 A \\
M Z\end{array}$ & Shorthorn & Shorthorn & 116 & $\begin{array}{l}146 \\
142\end{array}$ & 4 & $\cdots$ & 90 & $\ldots$ \\
\hline $\begin{array}{l}M Z \simeq 6 \mathrm{~A} \\
\mathrm{MZ} \times 6 \mathrm{~B}\end{array}$ & Welsh & Welsh & 90 & $\begin{array}{l}200 \\
198\end{array}$ & 6 & $\ldots$ & 82 & $\ldots$ \\
\hline
\end{tabular}

* All the animals were female except $M 3 A$ and $B$.

+ Homografts survived in all animals.

In the light of the findings of the next section, these reactions gave weak evidence of an exceedingly feeble and transient homograft reaction, so confirming the doubt that had arisen about the justice of the original classification. It will be noticed, however, that the initiative for the re-examination of the diagnosis came from the evidence of ordinary phenotypic appraisal and not from the evidence of grafting.

\section{(iii) The exchange of homografts between allegedly dizygotic twins of similar sex}

In this group of experiments skin homografts were exchanged between the members of 7 different pairs of allegedly dizygotic female twins. (A further group of experiments involving dizygotic twins of unlike sex will be described in a later section.) The obvious dissimilarity between the two members of most of the pairs made the likelihocd of faulty classification fairly remote.

In not a single animal did any of the homografts undergo the rapid, clear-cut breakdown that might have been anticipated from the results 
obtained when grafts were exchanged between unrelated animals, i.e. between animals of unquestionable genetic disparity.

In all these pairs of twins, irrespective of whether there had at any stage been the slightest indication of a reaction after the transplantation of the first set of homografts, a second set of homografts was subsequently exchanged, and in many this was followed by a third set of homografts, making a total dosage of 20-30 homografts

TABLE 3

\begin{tabular}{|c|c|c|c|c|c|c|c|c|c|c|c|}
\hline \multirow{3}{*}{ Number * } & \multirow{3}{*}{ Sire } & \multirow{3}{*}{ Dam } & \multicolumn{6}{|c|}{ At operation } & \multirow{3}{*}{$\begin{array}{c}\text { Total } \\
\text { number of } \\
\text { homografts } \\
\text { inter- } \\
\text { changed }\end{array}$} & \multirow{3}{*}{$\begin{array}{l}\text { Obser- } \\
\text { vation } \\
\text { period } \\
\text { (days) }\end{array}$} & \multirow{3}{*}{ Notes $\dagger$} \\
\hline & & & \multicolumn{2}{|c|}{$\begin{array}{l}\text { First } \\
\text { stage }\end{array}$} & \multicolumn{2}{|c|}{$\begin{array}{l}\text { Second } \\
\text { stage }\end{array}$} & \multicolumn{2}{|c|}{$\begin{array}{l}\text { Third } \\
\text { stage }\end{array}$} & & & \\
\hline & & & $\begin{array}{c}\text { Age } \\
\text { (days) }\end{array}$ & $\begin{array}{l}\text { Wt. } \\
\text { (lbs. }\end{array} \mid$ & $\begin{array}{c}\text { Age } \\
\text { (days) }\end{array}$ & $\begin{array}{l}\text { Wt. } \\
\text { (lbs.) }\end{array}$ & $\begin{array}{l}\text { Age } \\
\text { (days) }\end{array}$ & $\begin{array}{c}\text { Wt. } \\
\text { (lbs.) }\end{array}$ & & & \\
\hline $\begin{array}{ll}\mathrm{DZ} & 2 \mathrm{~A} \\
\mathrm{DZ} & 2 \mathrm{~B}\end{array}$ & Friesian & Ayrshire & 25 & $\begin{array}{l}87 \\
93\end{array}$ & 575 & $\begin{array}{l}750 \\
806\end{array}$ & $\cdots$ & $\cdots$ & 25 & 630 & $\begin{array}{l}\text { Delayed breakdown: } \\
\text { see text, section } 4 \text { (iii) }\end{array}$ \\
\hline $\begin{array}{l}\text { DZ } 10 A \\
D Z_{1 O B}\end{array}$ & Friesian & Shorthorn & 224 & $\begin{array}{l}407 \\
369\end{array}$ & 466 & $\begin{array}{l}780 \\
708\end{array}$ & $\cdots$ & $\cdots$ & 18 & 327 & See also section 4 (i) \\
\hline $\begin{array}{l}\mathrm{DZ} \text { IIA } \\
\text { DZ } 11 \mathrm{~B}\end{array}$ & Friesian & Ayrshire & 164 & $\begin{array}{l}221 \\
217\end{array}$ & 464 & $\begin{array}{l}732 \\
676\end{array}$ & $\cdots$ & $\cdots$ & 16 & 395 & $\begin{array}{l}\text { Transient reaction: } \\
\text { see text, secticn } 4 \\
\text { (iii), see also section } \\
\quad 4 \text { (i) }\end{array}$ \\
\hline $\begin{array}{l}\text { DZ } 14 \mathrm{~A} \\
\text { DZ }\end{array}$ & Shorthorn & Shorthorn & 198 & $\begin{array}{l}277 \\
293\end{array}$ & 429 & $\begin{array}{l}624 \\
644\end{array}$ & 450 & $\begin{array}{l}624 \\
644\end{array}$ & 32 & 327 & $\begin{array}{l}\text { Transient reaction : see } \\
\text { text, section } 4 \text { (iii) }\end{array}$ \\
\hline $\begin{array}{l}\mathrm{DZ} \times 5^{\mathrm{A}} \\
\mathrm{DZ}\end{array}$ & Ayrshire & Shorthorn & 133 & $\begin{array}{l}218 \\
255\end{array}$ & 375 & $\begin{array}{l}626 \\
679\end{array}$ & 422 & $\begin{array}{l}651 \\
688\end{array}$ & 40 & 348 & $\cdots$ \\
\hline $\begin{array}{l}D Z 16 \mathrm{~A} \\
\mathrm{DZ} \\
16 \mathrm{~B}\end{array}$ & Friesian & Friesian & 80 & $\begin{array}{l}140 \\
116\end{array}$ & 322 & $\begin{array}{l}494 \\
468\end{array}$ & 343 & $\begin{array}{l}494 \\
468\end{array}$ & $\begin{array}{l}33 \text { on } 16 \mathrm{~A} \\
39 \text { on } 16 \mathrm{~B}\end{array}$ & 338 & $\cdots$ \\
\hline
\end{tabular}

- All animals female.

$\dagger$ Survival of homografts on all animals except DZ $2 \mathrm{~A}$ (see text).

per animal. These subsequent transplantations were carried out in an attempt to increase the actual dosage of "foreign" skin born by the animals and thereby elicit or at least augment the reaction that the first set of grafts evidently failed to provoke.

These seven pairs of twins were observed at regular intervals over a considerable period of time (300-40o days). In four pairs there was not the slightest indication of a reaction-the grafts behaved like autografts in all respects, save of course with regard to their colour, which remained donor specific. In two pairs only was there evidence of a distinct though considerably delayed reaction; in a third pair there was no more than a suspicion of a reaction. These animals will now be described in further detail.

DZ $2 \mathrm{~A}$ and 2B.-Single black homografts were interchanged and grafted to white areas. The homograft from $2 \mathrm{~B}$ on $2 \mathrm{~A}$ provoked a chronic lowgrade and apparently cyclical (as opposed to progressive) inflammatory reaction, associated with scabbing and partial loss of its surface epithelium. The reaction was first recorded at a routine inspection on the 167 th day, 
and it culminated in apparent breakdown by the 204th day. The interpretation of the fate of the graft was complicated by the progressive development and persistence of a wide band of pigment spread into the white skin around it.

After 550 days a second set of 24 homografts was exchanged between the pair; and though the grafts appeared perfectly normal as late as the $34^{\text {th }}$ day after grafting, they eventually elicited a reaction which culminated in total breakdown by the 6oth day (plate 2, figs. 12, 13). The band of pigment spread around the original homograft was quite unaffected by the reaction-an apparent anomaly discussed in detail by Billingham and Medawar (1950), who have given evidence that such pigmentation is not due to the survival of foreign pigmentary cells.

The grafts from $2 \mathrm{~A}$ on $2 \mathrm{~B}$ showed absolutely no trace of a homograft reaction at any stage.

DZ IIA and I IB.--In this pair the story is essentially the same. In the first stage operation, four black ear skin homografts were interchanged, and in both animals they elicited a low-grade chronic reaction with persistent scaling and scabbing of the grafts and erosion of the surface epithelium. In this pair, as in $\mathrm{DZ}_{2}$, the interpretation was complicated by the progressive development and persistence of pigment spread, but breakdown was almost certainly complete by the 69 th day, if not earlier. The second stage operation was done 300 days after the first, and 12 homografts were interchanged.

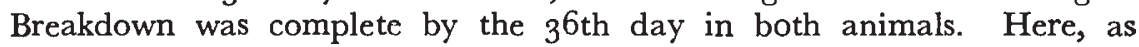
before, the annuli of pigment spread from the original homografts was unaffected (plate I, figs. 4, 9).

DZ $14 \mathrm{~A}$ and $14 \mathrm{~B}$.- - Four red ear skin homografts were interchanged at the first stage operation and remained perfectly normal to outward appearance throughout. Twenty-four red ear skin homografts were interchanged at the second stage operation 252 days later: these went through an inflammatory phase, more pronounced in $14^{\mathrm{B}}$ than in $14^{\mathrm{A}}$, but thereafter settled down to normality.

In summary, the results of exchange transplantation on our seven pairs of dizygotic twins of similar sex may be classified thus : (a) four pairs in which the homografts remained perfectly normal throughout ; (b) one pair in which a perceptible, but trivial and transitory homograft reaction was elicited; $(c)$ two pairs in which a feeble, dilatory and long drawn out reaction eventually culminated in the destruction of the foreign skin.

We now turned to consider two hypotheses which, however improbable, might conceivably account for this anomalous behaviour :

(I) That the cattle were of a sufficiently high level of inbreeding to reduce the homograft reaction to one of trivial and, in most cases, imperceptible intensity. This possibility could clearly be checked by grafting between siblings of the same breeds but of separate birth, as described in section (iv). The prima facie case for this hypothesis was clearly weakened by the violence of the homograft reaction between cattle of the same breed though not of close familial relationship, together with the prolonged inbreeding known to be required 
by mice before the skin homograft reaction is reduced to an intensity which allows the prolonged or indefinite survival of foreign skin.

(2) That the majority of the twins classified as dizygotic were in fact monozygotic. To refute this hypothesis, grafts were interchanged between dizygotic twins of dissimilar sex. Had we not started with the reasonable presumption that homografts on cows would behave in a manner analagous to homografts on the common laboratory mammals, these tests would of course have been made at a much earlier stage. They are described in section (v).

\section{(iv) Exchange transplantations between full siblings of separate birth}

The experiments to be described in this section comprise two independent tests of exactly similar design. In each test we made use of two (allegedly) monozygotic * female twins and a younger full sister; the group of three was so operated upon that each animal received six homografts from each of its sisters and six autografts from itself (fig. 2).

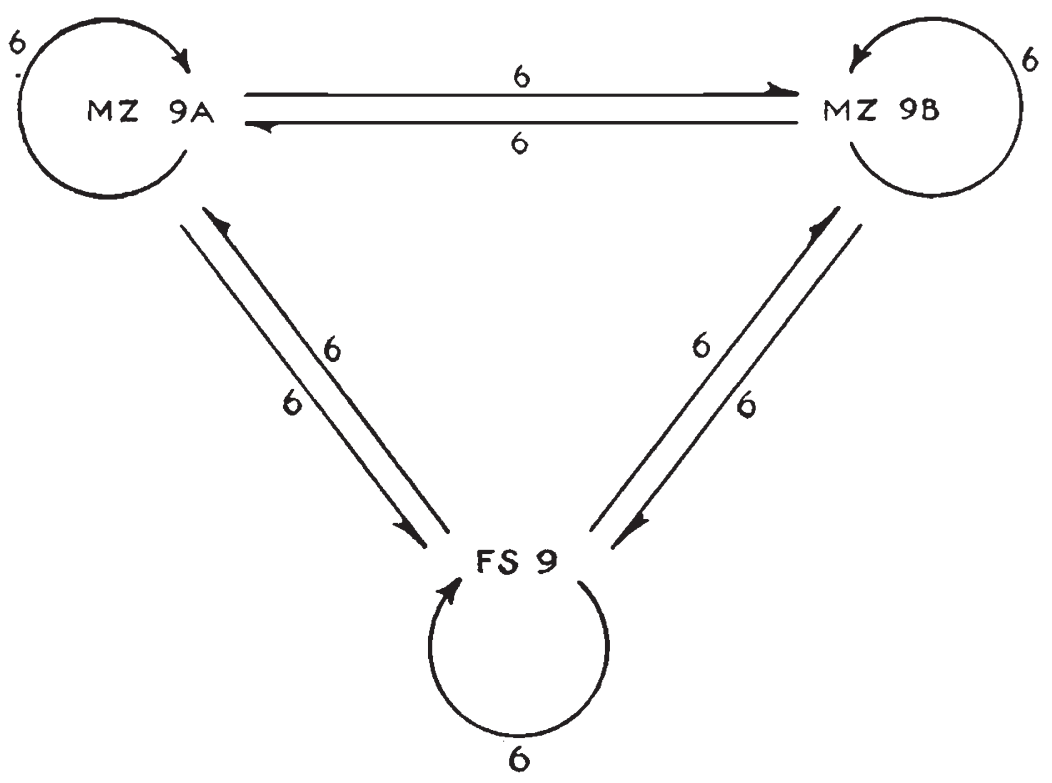

Fic. 2. - To illustrate the transplantations carried out between full siblings of separate birth. Animals $\mathrm{MZ} 9 \mathrm{~A}$ and $\mathrm{B}$ were classified as monozygotic female twins, while FS 9 was a younger full sister. Each animal received 6 homografts from each of its sisters and six autografts from itself.

The results of both groups of tests were incisively sharp. The six homografts which the younger full sister received from each of the grown-up twins had become completely necrotic by the $15^{\text {th }}$ day. The six homografts transplanted from the younger sister to each of the grown up twins broke down more quickly still. The autografts,

\footnotetext{
* Dizygotic twins would clearly have been preferable, but they were not available.
} 
and the grafts exchanged between the twins, remained perfectly normal throughout. The violence of the homograft reaction is made clear by plate 2 , figs. io, i I.

TABLE 4

\begin{tabular}{|c|c|c|c|c|c|}
\hline No. & Sire & Dam & Age (days) & Wt. (lbs.) & $\begin{array}{c}\text { Observation } \\
\text { period (days) }\end{array}$ \\
\hline $\begin{array}{ll}\mathrm{MZ} & 9^{\mathrm{A}} \\
\mathrm{MZ} & 9^{\mathrm{B}} \\
\mathrm{FS} & 9\end{array}$ & Shorthorn & Guernsey & $\begin{array}{r}539 \\
175\end{array}$ & $\left\{\begin{array}{l}802 \\
756 \\
200\end{array}\right.$ & 43 \\
\hline $\begin{array}{l}\text { MZ I3A } \\
M Z \text { I } \\
\text { FS } 13\end{array}$ & Shorthorn & Shorthorn $\times$ Friesian & $\begin{array}{r}489 \\
27\end{array}$ & $\left\{\begin{array}{l}713 \\
689 \\
110\end{array}\right.$ & 18 \\
\hline
\end{tabular}

For the plan and results of the experiment, see fig. 2 and text above.

See also section 4 (ii) for pairs $M Z_{9}$ and $M Z_{13}$.

It was concluded that siblings of separate birth are in no wise exempt from the ordinary consequences of skin transplantation immunity.

(v) Exchange transplantations between dizygotic twins of unlike sex

Grafts were interchanged between three pairs of twins of unlike sex and kept under observation for not less than seventy-one days.

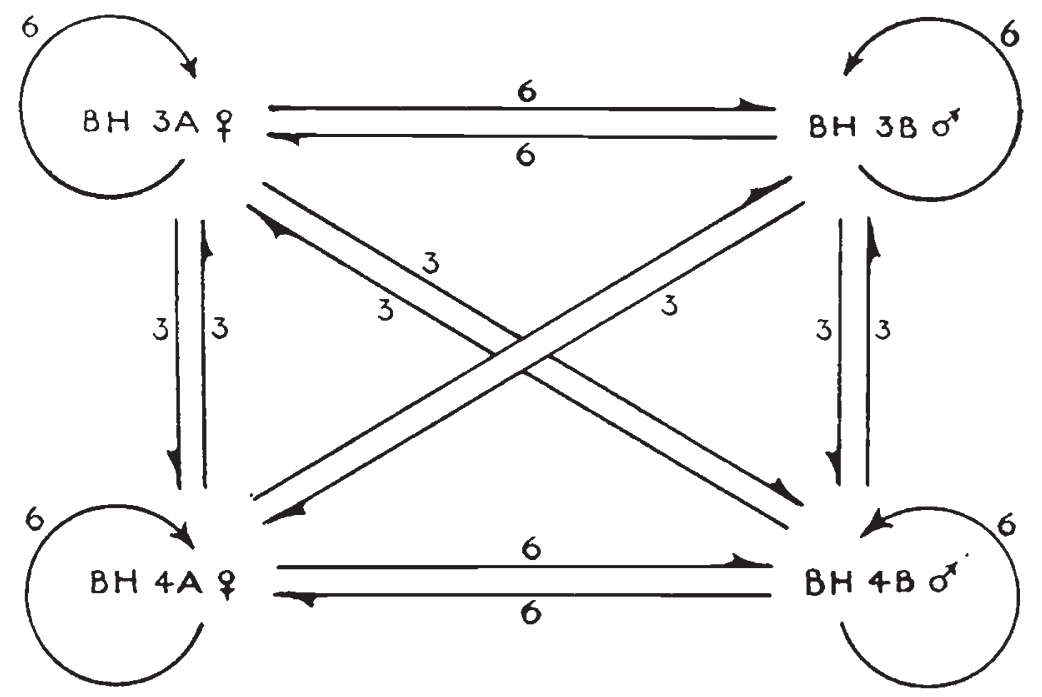

Fig. 3-Illustrating the transplantations carried out between two pairs of dizygotic twins of opposite sex so that each animal received six autografts, six homografts from the other member of its pair, and three homografts from each member of the other pair of twins.

The results prove without ambiguity that dizygotic twins of unlike sex are completely tolerant to grafts of each other's skin. 
$\mathrm{BH}$ IA (male: red roan) and $\mathrm{BH}$ I B (female: blue roan i.e. with some mixture of white hairs with the black).-Each member of the pair received 6 autografts and 6 homografts from the other member of the pair. The female was destroyed on the 7ist day after operation, and dissection of the reproductive system confirmed that it was a freemartin. Its homografts remained perfectly normal-i.e. autograftlikethroughout, both microscopically and to outward appearance (plate 2, figs. I 8, I9). The homografts on $\mathrm{BH}$ i a were observed for 124 days. A biopsy specimen taken at the 4 Ist day gave histological evidence of a very weak homograft reaction in the form of circumscribed perivascular clusters of round cells (plate 2 , figs. 16,17 ), but the reaction did not progress and the grafts returned to normal.

BH 3A (female: black and white) and $\mathrm{BH} 3^{\text {B }}$ (male: blue roan); $\mathrm{BH}$ 4A (female: red and white) and $\mathrm{BH} 4 \mathrm{~B}$ (male: red and white).

TABLE 5

\begin{tabular}{|c|c|c|c|c|c|c|}
\hline \multirow{2}{*}{ No. } & \multirow{2}{*}{ Sire } & \multirow{2}{*}{ Dam } & \multicolumn{2}{|c|}{ At operation } & \multirow{2}{*}{$\begin{array}{c}\text { Observation } \\
\text { period (days) }\end{array}$} & \multirow{2}{*}{ Notes * } \\
\hline & & & Age (days) & $\begin{array}{l}\text { Wt. (lbs.) } \\
\text { (approx.) }\end{array}$ & & \\
\hline $\begin{array}{l}\mathrm{BH} \text { I } \mathrm{A}(\mathrm{M}) \\
\mathrm{BH} \text { I } \mathrm{B}(\mathrm{F})\end{array}$ & Shorthorn & $\begin{array}{l}\text { Shorthorn } \\
\times \text { Friesian }\end{array}$ & 55 & 170 & $\begin{array}{r}124 \\
7 \mathrm{I}\end{array}$ & Freemartin \\
\hline $\begin{array}{l}\mathrm{BH} 3^{\mathrm{A}}(\mathrm{F}) \\
\mathrm{BH} 3^{\mathbf{B}}(\mathrm{M})\end{array}$ & Shorthorn & Friesian & 29 & 100 & ro9 & Freemartin \\
\hline $\begin{array}{l}\mathrm{BH} 4^{\mathrm{A}}(\mathrm{F}) \\
\mathrm{BH} 4^{\mathrm{B}}(\mathrm{M})\end{array}$ & Ayrshire & Ayrshire & 27 & 80 & $\begin{array}{l}109 \\
\text { Died }\end{array}$ & Freemartin \\
\hline
\end{tabular}

The plan and results of the operations are described in the text and shown in fig. 3 .

* See also section 4 (i) for pairs $\mathrm{BH}$ I and $\mathrm{BH} 2$.

These two pairs of animals were operated upon in a single group : each animal received 6 autografts, 6 homografts from the other member of its pair, and three homografts from each of the two members of the other pair (fig. 3). $\mathrm{BH} 4 \mathrm{~B}$ unfortunately died within 24 hours of operation; the other three received their last inspection $\mathrm{I} 09$ days after operation. All the homografts exchanged between the members of a twin pair remained to outward appearance perfectly normal throughout (plate 2, figs. 14, 15). The homografts transplanted between individuals of different pairs all broke down by the $5^{\text {th }}$ day, though not simultaneously (see Discussion p. 394.)

Both females proved on autopsy to be freemartins.

These results exactly confirm those found by exchanging grafts between dizygotic twins of like sex and so make it unnecessary to enquire further into the possibility that all the latter were in reality monozygotic. 


\section{DISCUSSION}

\section{(i) The use of skin grafting for twin diagnosis in cattle}

The practical import of the work described above is that graft interchange cannot be used as a method for distinguishing between twins of monozygotic and dizygotic origin in cattle. Experiments are now to be begun that make use of a different principle : the grafting of skin from both members of a twin pair to a third animal unrelated to either. As a further refinement, the recipient might be immunised beforehand by grafts from one only of its two donors. Even small differences between the breakdown times of the grafts and the severity of the histological reactions they elicit would give evidence of a genetic disparity between the two donors; for it is already known $(a)$ that orthotopic skin grafts of a genetically uniform population behave identically, even in the finest histological detail, when grafted simultaneously to a single recipient (Medawar, 1945), and (b) that grafts transplanted from a variety of donors to a single recipient differ very widely in their survival times and in the violence of the reactions they provoke (Medawar, I945; $c f$. also Billingham and Medawar, 1950).

Preliminary results from the interchange of grafts between pairs $\mathrm{BH}_{3}$ and $\mathrm{BH}_{4}$ (see section $\mathrm{v}$ ) show that the method described in this section is worth further investigation.

\section{(ii) The cause of the anomalous behaviour of grafts exchanged between dizygotic twins}

The bare fact revealed by the experiments described in this paper is that skin homografts interchanged between dizygotic twins are in a high degree, though not always, mutually acceptable. To say that dizygotic twins are mutually "desensitised" to grafts of each other's skin is to hint at one possible explanation of this anomaly. In its technical sense, "desensitisation" refers to an acquired indifference to an otherwise active antigen that may be achieved by prolonged exposure to the antigen in very low, or initially very low, doses. It is not yet known whether or not minute ascending doses of tissue homografts can confer tolerance upon their recipients, but there is clear evidence that a naturally-occurring process analagous to desensitisation occurs in dizygotic bovine twins. Lillie's (1916, I917) endocrinological interpretation of the " freemartin" condition in the female member of dizygotic twins of unlike sex ( $c f$. also Tandler and Keller, I 9 I I)turns upon the fact that bovine twins, normally synchorial, actually establish a vascular anastomosis during uterine life. It is also a fact that the majority of dizygotic twins have identical red cell antigens (Owen, 1945; Owen, Davis and Morgan, 1946), although upwards of 40 red cell antigens are known in cattle (Ferguson, 1940; Ferguson, Stormont and Irwin, I942 ; Stormont and Cumley, 1943) and uniformity of red cell antigens between sibs other than twins is 
rare. Owen has produced evidence that the blood of dizygotic twin cattle may contain a mixture of red cells of different antigenic type ; since red cells do not reproduce and have short lives, he infers that red cell precursors are interchanged between the twins in utero and survive thereafter as cellular homografts. The dizygotic twin calf at birth is already, in fact, a genetical chimæra.* The experiments described in this paper provide direct confirmation of Owen's hypothesis.

In one important respect the mechanism of acquired tolerance to tissue homografts in twin cattle differs from desensitisation in the ordinary sense. The embryo is immunologically inactive : it does not manufacture antibodies and cannot therefore be said to become "desensitised" to an antigen to which it is not in any case sensitive. It may be that a desensitisation analagous to that conferred by minute increasing doses of an allergen occurs when, in fotal life, an antigen confronts the embryo's gradually awakening faculty of immunological response. There may also be the more profound theoretical reasons adduced by Burnet and Fenner (1949) for supposing that animals become unresponsive to potential antigens to which they are exposed as embryos. The whole problem of embryonic adjustment and response to antigens is to receive a fuller analysis than is made possible by experiments on cattle. In the meantime, it will be noticed that our own experimental results relate to young cattle only: we have no evidence of the behaviour of homografts on cattle fully grown.

Dizygotic twin pairs are not always completely tolerant to grafts of each other's skin, and chronic breakdown reactions of delayed onset have been described in section (iii). The reason may be the same as that adduced by Ghapin (I9I7) to account for variations in the degree of sexual abnormality to be found in freemartins; i.e. that it is due to differences between the times in fotal life at which vascular anastomosis is established, and possibly between the degrees of anastomosis achieved.

One possible, but very specialised use of graft interchange methods may be mentioned. If our interpretation - in all essentials Owen'sis correct, then dizygotic twins that do not establish a vascular anastomosis in utero should not be tolerant to grafts of each other's skin. The female member of a pair of unlike sex should, moreover, not be a freemartin. It follows that exchange transplantation should be able to discriminate at a very early age between freemartins and sexually normal females, though it may well prove that blood typing methods (Owen, 1945) are better. A second possibility of much wider import is the field of research that is now shown to be open

* In the current embryological (which is also the classical) sense, a "chimaera" is an organism whose cells derive from two or more distinct zygote lineages, and this is the sense which the term "genetical chimaera" is here intended to convey. "Genetical mosaic" is less suitable, because a mosaic is formed of the cells of a single zygote lineage. In a sense, the dizygotic cattle twin is what the botanist would call a " graft hybrid." 
to the grafting of tissues between animals of very different genetical constitutions. We are proposing to study the possible desensitisation of mouse embryos by inoculated foreign cells with this object specially in mind.

It may seem surprising that the interchange of red cell precursors should confer tolerance upon homografts of, effectively, skin epithelium; but it should be pointed out $(a)$ that there is already known to be some degree of overlap between the antigens of leucocytes and of skin epithelium (Medawar, I 946b), and (b) that red-cell precursors are not likely to be the only cells that are interchanged. Leucocyte precursors are certain to be among them. The fact that the dizygotic twin cow is a genetical chimara-in particular, that the freemartin contains genetically male cells-may make it necessary to qualify and enlarge the purely humoral interpretation of the freemartin condition : its shortcomings are now well known (Moore, 1947).

The peculiar violence of the homograft reaction in cows still requires an explanation.

In the light of our findings, it is reasonable to suppose that the apparently anomalous survival into the adult life of birds of cellular or even organ homografts transplanted into embryos ( $c f$. the review by Rawles, I948) will prove to have the same explanation as the tolerance of dizygotic twin cows to grafts of each other's skin-except that, in birds, the inoculation of embryos with foreign embryonic cells is brought about by experimental artifice and not by natural means.

\section{SUMMARY}

An investigation has been made of the value of skin grafting for discriminating between monozygotic and dizygotic cattle twins, in accordance with the general rule that skin grafts exchanged between genetically dissimilar mammals are rapidly destroyed.

Skin was accordingly interchanged between cattle of the following degrees of affinity :--

(I) Unrelated animals, individually of twin birth; animals related only by being of the same pedigree breed, and individually of separate birth.

(2) Full siblings of separate birth.

(3) Dizygotic twins of unlike sex.

(4) Twins of similar sex classified by ordinary phenotypic appraisal as dizygotic.

(5) Twins classified by ordinary phenotypic appraisal as monozygotic.

Both monozygotic and dizygotic twins are tolerant to grafts of each other's skin. Skin grafts interchanged between animals of the other degrees of affinity are very rapidly destroyed.

Not all dizygotic twin pairs are completely tolerant to grafts of 
each other's skin, and examples of chronic low-grade immunity reactions are reported.

It is suggested that the anomalous tolerance of dizygotic cattle twins to grafts of each other's skin has the same origin as their conformity of immunological blood types.

The work described in this paper was done at Cold Norton Farm (Stone, Staffordshire), one of the experimental farms of the Agricultural Research Council's Animal Breeding and Genetics Research Organisation. Miss Jean Morpeth gave valuable technical assistance throughout. In addition, we wish to thank $\mathrm{Mr}$ W. S. Biggar and Mr J. S. Tavernor for their friendly co-operation and practical help; and the work in all its stages has benefited greatly from thorough discussion with Dr H. P. Donald. The autopsies that verified the freemartin condition were done by Mr I. G. Shaw, M.R.c.v.s., to whom we are much obliged.

\section{REFERENCES}

BIllingham, R. E., KROHN, P. L., AND MEDAWAR, P. B. I951. Brit. med. F. i., I 57 .

BILlingham, R. E., AND MEDAWAR, P. B. I 948. Heredity, 2, 29.

BILlingham, R. E., AND MEDAWAR, P. B. I950. Heredity, 4, I4I.

BILlingham, R. E., AND MEDAWAR, P. B. I95I. Brit. F. exp. Biol. $28,385$.

BURnet, F. M., AND Fenner, F. I 949 . The Production of Antibodies. Melbourne.

ChAPIN, C. L. I II 7. F. $\exp$. Zool., 23, 453.

FERGUSON, L. C. I940. 7. Immunol., 40, 2 I3.

FERGUSON, L. G., STORMONT, C., AND IRWIN, M. R. I942. F. Immunol., 44, I47.

franceschetti, A., Bamatter, F., AND klein, D. I948. Bull. Acad. suisse Sci. med, 4,433 .

LILLIE, F. R. IgI6. Science, 43, 6I I.

LILLIE, F. R. I9I7. 7. exp. Zool., 23, 37I.

maindoe, A., AND FRANCESChETti, A. I 950. Brit. 7. plastic Surg., 2, 283.

MEDAWAR, P. B. I 944 . 7. Anat., Lond., 78 , 176.

MEDAWAR, P. B. I 945 . 7. Anat., Lond., 79, 157.

MEDAWAR, P. B. I $946 a$. Brit. F. exp. Path., 27, 9.

Medawar, P. B. I $946 b$. Brit. 7. exp. Path., 27, 15.

MOORE, G. R. I 947. Embryonic Sex Hormones and Sexual Differentiation. Springfield. OWEN, R. D. I 945 . Science, 102, 400.

OWEN, R. D., DAVIS, H. P., AND MORGAN, R. F. I 946. 7. Hered., 37, $29 \mathrm{I}$.

RAWles, M. I948. Physiol. Rev., 28,383 .

STORMONT, C., AND CUMLEy, R. w. I 943 . 7. Hered., 34, 35.

TANDler, J., AND Keller, K. I9i I. Dtsch. Tierärtzl. Woch., rg, I48. 